\title{
Potential Antimicrobial Applications of Chitosan Nanoparticles (ChNP)
}

\author{
Nur Amiera Syuhada Rozman ${ }^{1}$, Tong Woei Yenn ${ }^{1 *}$, Leong Chean Ring ${ }^{1}$, Tan Wen Nee ${ }^{2}$, Muhammad Ariff \\ Hasanolbasori ${ }^{3}$, and Siti Zubaidah Abdullah ${ }^{1}$ \\ ${ }^{1}$ Universiti Kuala Lumpur, Branch Campus Malaysian Institute of Chemical and Engineering Technology, Lot 1988 Kawasan Perindustrian \\ Bandar Vendor, Taboh Naning, 78000 Alor Gajah, Melaka, Malaysia \\ ${ }^{2}$ School of Distance Education, Universiti Sains Malaysia, 11800 Gelugor, Pulau Pinang, Malaysia \\ ${ }^{3}$ Nanotechnology and Catalyst Research Centre (Nanocat), University of Malaya, 50630 Kuala Lumpur, Malaysia
}

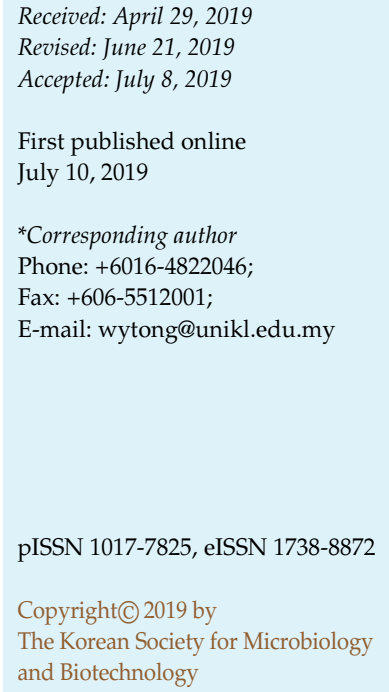

Polymeric nanoparticles are widely used for drug delivery due to their biodegradability property. Among the wide array of polymers, chitosan has received growing interest among researchers. It was widely used as a vehicle in polymeric nanoparticles for drug targeting. This review explored the current research on the antimicrobial activity of chitosan nanoparticles $(\mathrm{ChNP})$ and the impact on the clinical applications. The antimicrobial activities of ChNP were widely reported against bacteria, fungi, yeasts and algae, in both in vivo and in vitro studies. For pharmaceutical applications, ChNP were used as antimicrobial coating for promoting wound healing, preventing infections and combating the rise of infectious disease. Besides, ChNP also exhibited significant inhibitory activities on foodborne microorganisms, particularly on fruits and vegetables. It is noteworthy that ChNP can be also applied to deliver antimicrobial drugs, which further enhance the efficiency and stability of the antimicrobial agent. The present review addresses the potential antimicrobial applications of ChNP from these few aspects.

Keywords: Chitosan, nanoparticle drug delivery, chitosan nanoparticle, microbial infection

\section{Introduction}

Chitosan, a derivative of chitin is a cationic polysaccharide composed of $\mathrm{N}$-acetyl glucosamine and $\mathrm{D}$ glucosamine [1]. Interestingly, chitosan consists of several functional groups which can be modified for numerous applications. Chitosan has been recognized as a versatile biopolymer because of its non-toxicity, biocompatibility, low allergenicity and biodegradability properties [2]. Chitosan is also classified as safe to be used by the US Food and Drug Administration (FDA) for wound dressing applications [3]. However, chitosan is a weak base and it has low solubility in neutral and alkaline media which limits its applications. Nevertheless, this limitation can be overcome by improving the formulation [4]. The most significant characteristic of this biopolymer which makes it able to adhere to the scaffold is the high porosity characteristic [5]. In addition, chitosan is the only biodegradable polymer that exhibits cationic character because of its primary amino groups [6]. Furthermore, chitosan and chitin have been employed as a base material in nanotechnology application. Besides, chitosan shows significant antimicrobial properties because it binds the negatively charged residues of the bacterial cell wall. Electrostatic force between positively charged chitosan promotes a closer interaction with negatively charged bacteria cell wall, that leads to the penetration of drug through the bacteria cell wall. This is because bacterial cell wall is made up with a layer of peptidoglycan which is rich in negatively charged carboxyl and amino groups [7]. So, the potential of chitosan to gather at the site of infection will increase. Chitosan is also able to alter the electron transport chain of bacterial membranes [8]. This system is responsible to generate electron carriers and builds a proton gradient in the inner membrane of mitochondria, which is important for ATP production [9]. The antimicrobial activity of chitosan depends on the type of chitosan, degree of deacetylation and most importantly, the molecular weight [10]. Other 
than that, lower molecular weight chitosan can enter the cell, binds to DNA and inhibits RNA and protein synthesis [9]. Since chitosan could adsorb the electronegative substances in the cell and flocculate them, it disturbs the physiological activities of the microorganism which eventually leads to death of the cells [11].

\section{Drug Delivery}

For decades, polymers such as chitosan have been utilized as carriers to provide a safe passage for delivery of bioactive compounds. Due to their good biodegradability and versatility, they can breakdown into non-toxic metabolites that can be eliminated easily [12]. Due to its high porosity, chitosan is also widely used as wound dressing and tissue scaffolding material. Chitosan also exhibits muco-adhesive, permeation-enhancing and efflux pump inhibitory properties [13]. Nanoparticles offer a novel delivery system in order to improve the distribution of drugs in different target routes and overcome the cellular barriers [14]. Chitosan improved the delivery of drugs in therapeutic studies. There are several possible drug release mechanisms of chitosan nanoparticles including diffusion of adsorbed drug, swelling of polymer matrix and erosion of chitosan matrix [11]. Chitosan nanoparticle size and surface profiles can be easily modified either as passive or active drugs targeting the different target routes [9]. In case of drug release, nanoparticles are established to exhibit sustained drug release, and also to reduce toxicity and side effects of drugs on the therapeutics system [12]. The role of chitosan nanoparticles in antimicrobial drug delivery is summarized in Table 1.

There are several common techniques to prepare chitosan-based nanoparticles such as ionic gelation, covalent cross linking, precipitation, polymerization, selfassembly, chitosan-drug complexes and spray-drying [15]. Furthermore, several types of chitosan drug delivery systems are available for different application sites, for example; oral, ocular, nasal, vaginal, buccal, vaccine, parental and intra-vesical drug delivery [16]. Other than that, doxorubicin chitosan-based nanoparticle displayed higher encapsulation efficiency with up to $70 \%$ doxorubicin encapsulated [17]. Similarly, another study also obtained a higher encapsulation efficiency of Protein/siRNA in chitosan, compared to other biopolymers [18]. In contrast, an encapsulation efficiency of less than $50 \%$ was reported on 5-fluorouracil-loaded chitosan nanoparticles reported by Sun and colleagues [19]. Nevertheless, the nanoparticles exhibit a sustained-release pattern compared to 5fluorouracil solution, which can significantly improve the resident time of drug in the human body. Banik et al. [20] prepared nanoparticles of chitosan-montmorillonite loaded with isoniazid drug to study the effect of particle size on the release profile. Their results showed that with the decreasing of nanoparticle sizes, the cumulative percentage of drug release was increased but the cytotoxicity also increased. However, the cytotoxicity can be decreased with incorporation of clay into the system. Furthermore, chitosan was utilized for nano-encapsulation of rosemary essential oil by Hussein et al. [21]. They reported a significant improvement in thermal stability of rosemary essential oil after the nano-encapsulation process. Chitosan has a suitable matrix for the encapsulation due its cationic characteristic.

\section{Antifungal Activity}

Generally, chitosan nanoparticles are effective in inhibiting spore germination and radial mycelial growth [22]. Numerous studies have been conducted on yeast and molds associated with food and plant contamination. Using ionic gelation method, Saharan et al. [23] prepared chitosan nanoparticles loaded with copper $(\mathrm{Cu})$ ions to test antifungal efficacy against pathogenic fungi on tomato. The nanoparticles exhibited positive charge $(+22.6 \mathrm{mV})$ zeta potential thus improving stability of particles and enhancing more electrostatic interaction with cell membrane pathogenic fungi. Cota-Arriola et al. [24] suggested the efficacy of ChNP antifungal activity on Aspergillus parasiticus was associated with particle size and matrix between chitosan and sodium tripolyphosphate. Pilon et al. [25] examined the use of chNP as a coating material to control microbial growth on fresh-cut apples. Their results showed that nanoparticles with a diameter of $110 \mathrm{~nm}$ were most effective in inhibiting the growth of mesophilic and psychrotrophic microorganisms. Recently, a comparative study was performed by Kheiri et al. [26] to evaluate the antifungal activity of chitosan and chNP against Fusarium graminearum. In this study, chitosan showed a weaker antifungal activity compared to chNP, which was evidenced by the higher minimal inhibitory concentration $50 \%\left(\mathrm{MIC}_{50}\right)$ value. Due to its small size, chitosan nanoparticles are easily diffused into the cell membrane of microorganisms. Antifungal activities of chitosan with different molecular weights were compared by Hernandez-Lauzardo et al. [27] 
Table 1. The role of ChNP in antimicrobial drug delivery.

\begin{tabular}{|c|c|c|c|c|}
\hline Materials & Preparations & Particle size & Applications/results & References \\
\hline $\begin{array}{l}\text { ChNP loaded with } \\
\text { 5-fluorouracil }\end{array}$ & Ionic gelation method & $283.9 \pm 5.25 \mathrm{~nm}$ & $\begin{array}{l}\text { 5-fluorouracil-loaded ChNP sustained longer } \\
\text { drug release time compared to non-encapsulated } \\
\text { drug in vitro and in vivo. }\end{array}$ & [19] \\
\hline $\begin{array}{l}\text { Chitosan- } \\
\text { montmorillonite } \\
\text { nanoparticles loaded } \\
\text { with isoniazid }\end{array}$ & Ionic gelation method & 282.2 and $451.8 \mathrm{~nm}$ & $\begin{array}{l}\text { The release of isoniazid increased as the } \mathrm{pH} \text { of } \\
\text { medium decreased. The nanoparticles are suitable } \\
\text { as drug carriers in gastric } \mathrm{pH} \text {. }\end{array}$ & [20] \\
\hline $\begin{array}{l}\text { ChNP loaded with } \\
\text { rosemary essential oil }\end{array}$ & $\begin{array}{l}\text { Homogenization } \\
\text { technique }\end{array}$ & $10-20 \mathrm{~nm}$ & $\begin{array}{l}\text { The nano-capsulation process increased the } \\
\text { thermal stability of rosemary essential oil with } \\
\text { antioxidant potential. }\end{array}$ & [21] \\
\hline ChNP & $\begin{array}{l}\text { Nanoprecipitation and } \\
\text { nanoencapsulation } \\
\text { methods }\end{array}$ & $406.6 \pm 25.5 \mathrm{~nm}$ & $\begin{array}{l}\text { ChNP inhibited spore germination and radial } \\
\text { mycelial growth on Colletotrichum gloeosporioides } \\
\text { and Alternaria species. }\end{array}$ & [22] \\
\hline $\begin{array}{l}\text { ChNP loaded with } \\
\text { copper }(\mathrm{Cu})\end{array}$ & Ionic gelation method & $150.0 \mathrm{~nm}$ & $\begin{array}{l}\text { In vitro antifungal efficacy of } \mathrm{Cu}-\mathrm{ChNP} \text { showed } \\
\text { significant inhibition against pathogenic fungi on } \\
\text { tomato. }\end{array}$ & [23] \\
\hline ChNP & Ionotropic gelation method & $\begin{array}{l}80.0 \mathrm{~nm} \text { to } 20.0 \mu \mathrm{m} \\
\text { (depends on } \\
\text { concentrations) }\end{array}$ & $\begin{array}{l}\text { ChNP inhibited Aspergillus parasiticus in terms of } \\
\text { radial growth, spore germination, and } \\
\text { morphological changes. }\end{array}$ & [24] \\
\hline ChNP & $\begin{array}{l}\text { Polymerizing citric } \\
\text { acid in chitosan solution }\end{array}$ & $110.0 \mathrm{~nm}$ & $\begin{array}{l}\text { ChNP reduced microbial growth on fresh-cut apples, } \\
\text { while maintaining the food quality compared to } \\
\text { conventional gel coating. }\end{array}$ & [25] \\
\hline ChNP & Ionic gelation method & $80.9 \pm 35.5 \mathrm{~nm}$ & $\begin{array}{l}\text { ChNP inhibited the growth of Fusarium } \\
\text { graminearum by } 77.5 \% \text {. }\end{array}$ & [26] \\
\hline ChNP & Ionic gelation method & $240 \mathrm{~nm}$ & $\begin{array}{l}\text { The antibacterial efficiency was affected by } \\
\text { molecular weight of chitosan, sonication condition } \\
\text { and type of cross linker. }\end{array}$ & [28] \\
\hline $\begin{array}{l}\text { ChNP loaded with } \\
\text { ferrous }\left(\mathrm{Fe}^{2+}, \mathrm{Fe}^{3+}\right)\end{array}$ & Ionic gelation method & 206.4 and $195.2 \mathrm{~nm}$ & $\begin{array}{l}\text { ChNP loaded with } \mathrm{Fe}^{2+}, \mathrm{Fe}^{3+} \text { showed significantly } \\
\text { better antimicrobial activity than metal ions. }\end{array}$ & [29] \\
\hline $\begin{array}{l}\text { ChNP loaded with } \\
\text { gold nanoparticles } \\
\text { (CS-Au@MMT/ } \\
\text { gelatin) }\end{array}$ & $\begin{array}{l}\text { Chitosan as a reducing and } \\
\text { stabilizing agent in the } \\
\text { synthesis of nanoparticles }\end{array}$ & $8.32 \pm 1.97 \mathrm{~nm}$ & $\begin{array}{l}\text { CS-Au@MMT/gelatin dressing showed } \\
\text { significant antibacterial activity against } \\
\text { methicillin-resistant Staphylococcus aureus- } \\
\text { associated wound infection. }\end{array}$ & [30] \\
\hline ChNP & $\begin{array}{l}\text { Samples were dissolved in } \\
0.1 \mathrm{M} \text { sodium acetate } \mathrm{pH} 4.0 \\
\text { and irradiated in an ice bath } \\
\text { with an ultrasonic probe }\end{array}$ & $\begin{array}{l}\text { Low molecular } \\
\text { weight: } 425 \mathrm{~nm} \\
\text { Medium molecular } \\
\text { weight: } 403 \mathrm{~nm}\end{array}$ & $\begin{array}{l}\text { ChNP inhibited the growth of } E \text {. coli with same } \\
\text { MIC and MBC values. }\end{array}$ & [31] \\
\hline $\begin{array}{l}\text { ChNP loaded with } \\
\text { hybrid copper }\end{array}$ & $\begin{array}{l}\text { Copper nanoparticles were } \\
\text { synthesized into a chitosan, } \\
\text { starch and ascorbic acid } \\
\text { bio-friendly system }\end{array}$ & $131 \pm 36 \mathrm{~nm}$ & $\begin{array}{l}\text { ChNP loaded with hybrid copper exhibited } \\
\text { significant antibacterial activity against cariogenic } \\
\text { Streptococcus mutans that cause tooth decay. }\end{array}$ & [32] \\
\hline $\begin{array}{l}\text { ChNP loaded with } \\
\text { nisin }\end{array}$ & Ionic gelation method & $86 \pm 0.23 \mathrm{~nm}$ & $\begin{array}{l}\text { Microscopic observation showed that the cell } \\
\text { membranes of S. aureus and E. coli were destroyed } \\
\text { when treated with ChNP loaded with nisin. }\end{array}$ & [33] \\
\hline
\end{tabular}

against Rhizopus stolonifer (Ehrenb.:Fr.) Vuill. The results revealed that chitosan with low molecular weight exhibited the most significant inhibition of mycelial growth while chitosan with high molecular weight disrupted spore shape, sporulation and germination. 


\section{Antibacterial Activity}

The antibacterial activity of ChNP was documented against foodborne Escherichia coli O157:H7. The antibacterial efficiency was affected by the molecular weight of chitosan, sonication condition and type of cross linker [28]. Other than that, chitosan loaded with ferrous and ferric sulphate exhibited better antimicrobial activity against E. coli and Staphylococcus aureus compared to ChNP [29]. Moreover, in vivo rabbit wound healing model was used to study the efficiency of chitosan-gold nanoparticles blended with gelatin (CS-Au@MMT/gelatin) dressing [30]. They discovered the CS-Au@MMT/gelatin exhibited a significant growth reduction against methicillin-resistant $S$. aureus associated wound infection. In addition, ultrasound irradiation was used to study the antibacterial activity of chitosan nanoparticles on E. coli [31]. They discovered that the antibacterial efficiency of ChNP depends on the molecular weight of chitosan and $\mathrm{pH}$ of medium at 5.0. The antibacterial mechanisms of ChNPs involve cell wall interfering and penetration into the nuclei of the microorganisms. In the same year, hybrid copper-chitosan nanoparticles prepared by Covarrubias et al. [32] were reported to exhibit a significant antibacterial activity against cariogenic Streptococcus mutans that cause tooth decay. Microscopic observation showed that the cell membranes of $S$. aureus and E. coli were destroyed when treated with chitosan nanoparticles loaded with nisin [33].

In conclusion, ChNPs are one of the most versatile polymers used for the development of antimicrobial chemotherapies in therapeutics study. Based on the review, ChNP exhibited significant antimicrobial activity on a wide spectrum of microorganisms. Recently, in order to achieve the synergistic antimicrobial effect, ChNP was used to deliver various antimicrobial agents. As a sufficiently wide application of ChNP is foreseen, fundamental studies should be carried out to investigate the antimicrobial mode of action as well as the synergism mechanisms of ChNP.

\section{Acknowledgement}

This work was supported by grant from Short Term Research Grant Scheme, Universiti Kuala Lumpur [STR17076].

\section{Conflict of Interest}

The authors have no financial conflicts of interest to declare.

\section{Reference}

1. Elieh-Ali-Komi D, Hamblin MR. 2016. Chitin and chitosan: production and application of versatile biomedical nanomaterials. Int. J. Adv. Res. 4: 411-427.

2. Younes I, Rinaudo M. 2015. Chitin and chitosan preparation from marine sources. Structure, properties and applications. Mar. Drugs 13: 1133-1174.

3. Aljebory AM, Alsalman TM. 2017. Chitosan nanoparticles. Imp. J. Interdiscip. Res. 3: 233-242.

4. Cheung R, Ng T, Wong J, Chan W. 2015. Chitosan: an update on potential biomedical and pharmaceutical applications. Mar. Drugs 13: 5156-5186.

5. Zeng S, Liu L, Shi,Y, Qiu J, Fang W, Rong M, Gao W. 2015. Characterization of silk fibroin/chitosan 3D porous scaffold and in vitro cytology. PLoS One 10: e0128658.

6. Bernkop-Schnürch A, Dünnhaupt S. 2012. Chitosan-based drug delivery systems. Eur. J. Pharm. Biopharm. 81: 463-469.

7. Cava F, Lam H, De Pedro MA, Waldor MK. 2011. Emerging knowledge of regulatory roles of D-amino acids in bacteria. Cell. Mol. Life Sci. 68: 817-831.

8. Ivask A, ElBadawy A, Kaweeteerawat C, Boren D, Fischer H, Ji Z, et al. 2013. Toxicity mechanisms in Escherichia coli vary for silver nanoparticles and differ from ionic silver. ACS Nano 8: 374-386.

9. Birsoy K, Wang T, Chen WW, Freinkman E, Abu-Remaileh M, Sabatini DM. 2015. An essential role of the mitochondrial electron transport chain in cell proliferation is to enable aspartate synthesis. Cell 162: 540-551.

10. Joshi M, Ali SW, Purwar R. 2009. Ecofriendly antimicrobial finishing of textile using bioactive agents based on natural products. Indian J. Fibre Text. Res. 30: 295-304.

11. El-Tahlawy KF, El-Bendary MA, Elhendawy AG, Hudson SM. 2005. The antimicrobial activity of cotton fabrics treated with different crosslinking agents and chitosan. Carbohydr. Polym. 60: 421-430.

12. Joshi M, Ali SW. Purwar R. 2009. Ecofriendly antimicrobial finishing of textile using bioactive agents based on natural products. Indian J. Fibre Text. Res. 30: 295-304.

13. Borchard G, Lueßen HL, De Boer A, Verhoef, JC, Lehr CM, Junginger HE. 1996. The potential of mucoadhesive polymers in enhancing intestinal peptide drug absorption. III: Effects of chitosan-glutamate and carbomer on epithelial tight junctions in vitro. J. Control. Release 39: 131-138.

14. Lim EK, Jang E, Lee K, Haam S, Huh YM. 2013. Delivery of cancer therapeutics using nanotechnology. Pharmaceutics 5: 294-317.

15. Wang JJ, Zeng ZW, Xiao RZ, Xie T, Zhou GL, Zhan XR, et al. 2011. Recent advances of chitosan nanoparticles as drug carriers. Int. J. Nanomed. 6: 765-774.

16. Biranje SS, Madiwale PV, Patankar KC, Chhabra R, Dandekar-Jain P, Adivarekar RV. 2019. Hemostasis and 
anti-necrotic activity of wound-healing dressing containing chitosan nanoparticles. Int. J. Biol. Macromol. 121: 936-946.

17. Soares PI, Sousa AI, Silva JC, Ferreira IM, Novo CM, Borges JP. 2016. Chitosan-based nanoparticles as drug delivery systems for doxorubicin: Optimization and modelling. Carbohydr. Polym. 147: 304-312.

18. Katas H, Raja MAG, Lam KL. 2013. Development of chitosan nanoparticles as a stable drug delivery system for protein/siRNA. Int. J. Biomater. 2013: 146320.

19. Sun L, Chen Y, Zhou Y, Guo D, Fan Y, Guo F, et al. 2017. Preparation of 5-fluorouracil-loaded chitosan nanoparticles and study of the sustained release in vitro and in vivo. Asian J. Pharm. Sci. 12: 418-423.

20. Banik N, Hussain A, Ramteke A, Sharma HK, Maji TK. 2012. Preparation and evaluation of the effect of particle size on the properties of chitosan-montmorillonite nanoparticles loaded with isoniazid. RSC Adv. 2: 10519-10528.

21. Hussein AM, Kamil MM, Lotfy SN, Mahmoud KF, Mehaya FM, Mohammad AA. 2017. Influence of nano-encapsulation on chemical composition, antioxidant activity and thermal stability of rosemary essential oil. Am. J. Food Technol. 12:170-177.

22. Barrera-Necha LL, Correa-Pacheco ZN, Bautista-Baños S, Hernández-López M, Jiménez JEM, Mejía AFM. 2018. Synthesis and characterization of chitosan nanoparticles loaded botanical extracts with antifungal activity on Colletotrichum gloeosporioides and Alternaria species. Adv. Microbiol. 8: 286-296.

23. Saharan V, Sharma G, Yadav M, Choudhary MK, Sharma SS, Pal A, et al. 2015. Synthesis and in vitro antifungal efficacy of $\mathrm{Cu}$-chitosan nanoparticles against pathogenic fungi of tomato. Int. J. Biol. Macromol. 75: 346-353.

24. Cota-Arriola O, Cortez-Rocha MO, Ezquerra-Brauer JM, Lizardi-Mendoza J, Burgos-Hernández A, Robles-Sánchez RM, et al. 2013. Ultrastructural, morphological, and antifungal properties of micro and nanoparticles of chitosan crosslinked with sodium tripolyphosphate. J. Polym. Environ. 21: 971-980.
25. Pilon L, Spricigo PC, Miranda M, de Moura MR, Assis OBG, Mattoso LHC, et al. 2015. Chitosan nanoparticle coatings reduce microbial growth on fresh-cut apples while not affecting quality attributes. J. Food Sci. Technol. 50: 440-448.

26. Hussein AM, Kamil MM, Lotfy SN, Mahmoud KF, Mehaya FM, Mohammad AA. 2017. Influence of nano-encapsulation on chemical composition, antioxidant activity and thermal stability of rosemary essential oil. Am. J. Food Technol. 12: 170-177.

27. Hernandez-Lauzardo AN, Bautista-Baños S, Velazquez-Del Valle MG, Méndez-Montealvo MG, Sánchez-Rivera MM, Bello-Perez LA. 2008. Antifungal effects of chitosan with different molecular weights on in vitro development of Rhizopus stolonifer (Ehrenb.: Fr.) Vuill. Carbohydr. Polym. 73: 541-547.

28. Garrido-Maestu A, Ma Z, Chen N, Ko S, Tong Z, Jeong KC. 2018. Engineering of Chitosan-derived nanoparticles to enhance antimicrobial activity against foodborne pathogen Escherichia coli O157: H7. Carbohydr. Polym. 197: 623-630.

29. Qian J, Pan C, Liang C. 2017. Antimicrobial activity of Feloaded chitosan nanoparticles. Eng. Life Sci. 17: 629-634.

30. Lu B, Ye H, Shang S, Xiong Q, Yu K, Li Q, Lan G. 2018. Novel wound dressing with chitosan gold nanoparticles capped with a small molecule for effective treatment of multiantibiotic-resistant bacterial infections. Nanotechnology 29: 425603.

31. Gomes LP, Andrade CT, Del Aguila EM, Alexander C, Paschoalin VM. 2018. Assessing the antimicrobial activity of chitosan nanoparticles by fluorescence-labeling. Intl. J. Biotechnol. Bioeng. 12: 111-117.

32. Covarrubias C, Trepiana D, Corral C. 2018. Synthesis of hybrid copper-chitosan nanoparticles with antibacterial activity against cariogenic Streptococcus mutans. Dent. Mater. J. 37: 379-384.

33. Alishahi, A. 2014. Antibacterial effect of chitosan nanoparticle loaded with nisin for the prolonged effect. J. Food Saf. 34: 111-118. 